\title{
Numerical analysis of the indoor climate in a Zenith-type greenhouse in the Valle de Santiago region, Guanajuato
}

\section{Análisis numérico del clima interior en un invernadero tipo Cenital en la región de Valle de Santiago, Guanajuato}

\author{
MORALES-FÉLIX, Verónica de Jesús*†, RIVERA-ARREDONDO, Marisa, AGUIRRE-PUENTE, \\ José Alfredo and CALDERÓN-RUIZ, Alberto
}

\begin{abstract}
Universidad Tecnológica del Suroeste de Guanajuato, Carretera Valle-Huanímaro km. 1.2, Valle de Santiago, Guanajuato, 38400. México
\end{abstract}

ID $1^{\text {st }}$ Author: Verónica De Jesús, Morales-Félix

ID $1^{\text {st }}$ Coauthor: Marisa, Rivera-Arredondo

ID $2^{\text {nd }}$ Coauthor: José Alfredo, Aguirre-Puente

ID $3^{\text {rd }}$ Coauthor: Alberto, Calderón-Ruiz

DOI: 10.35429/JURRE.2020.6.4.1.4

Received March 11, 2020; Accepted June 30, 2020

\begin{abstract}
The objective of this project was to carry out an analysis of the indoor climate of the greenhouse located in the Valle de Santiago region, Guanajuato. It is a zenith-type greenhouse with two wings with a symmetrical face. An orthogonal mesh was made of 50 nodes ( 25 nodes for each height) Total Den located in the cultivable area and taking the value at the midpoint of each rectangle considering two heights $0.25 \mathrm{~m}$ and $1.30 \mathrm{~m}$ with respect to the ground. Humidity and temperature readings were taken in each of the nodes for three weeks and subsequently a data analysis was made and a comparison with the data collected in the different situations; also the temperature was analyzed with the double sum of Riemann and the rule of the middle point. In conclusion, it was determined that the greenhouse yields heat on warm days, while it receives heat on cold days. This behavior coincides with previous studies; however, it occurs that with the hydroponic method there is a greater growth of the crop.
\end{abstract}

Greenhouse, Indoor Climate, Temperature, Hydroponics, Heat, Mesh

\begin{abstract}
Resumen
El objetivo del presente proyecto fue realizar un análisis del clima interior del invernadero ubicado en la región de Valle de Santiago, Guanajuato. Es un invernadero tipo cenital con dos alas de cara simétrica. Se realizó un mallado ortogonal 50 nodos (25 nodos para cada altura) Den total ubicados en la zona cultivable y tomando el valor en el punto medio de cada rectángulo considerando dos alturas $0.25 \mathrm{~m}$ y $1.30 \mathrm{~m}$ con respecto al suelo. Se tomó lectura de humedad y temperatura en cada uno de los nodos durante tres semanas y posteriormente se hizo un análisis de datos y una comparación con los datos recolectados en las diferentes situaciones; además la temperatura se analizó con la doble suma de Riemann y la regla del punto medio. En conclusión, se determinó que el invernadero cede calor en los días cálidos, mientras que en los días fríos recibe calor, este comportamiento coincide con estudios previos; sin embargo, se observó que con el método de hidroponia hay un mayor crecimiento del cultivo.
\end{abstract}

Invernadero, Clima interior, Temperatura, Hidroponia, Calor, Mallado

Citation: MORALES-FÉLIX, Verónica de Jesús, RIVERA-ARREDONDO, Marisa, AGUIRRE-PUENTE, José Alfredo and CALDERÓN-RUIZ, Alberto. Numerical analysis of the indoor climate in a Zenith-type greenhouse in the Valle de Santiago region, Guanajuato. Journal-Urban-Rural and Regional Economy. 2020. 4-6: 1-4

\footnotetext{
* Correspondence to Author (email: vmoralesf@utsoe.edu.mx)

$\dagger$ Researcher contributing as first author.
} 


\section{Introduction}

A greenhouse is a covered and artificially closed installation with transparent materials, in most cases, in order to protect the plants from bad weather conditions (low temperatures, strong winds, hail, storms, low air humidity or excessive radiation solar) (Mejía - Sáenz, 2016). Ventilation is essential in a greenhouse. Maintaining a favorable indoor climate implies evacuating the excess heat produced at times of high insolation (Montero et al., 2001). Consequently, a good design of the ventilation systems of a greenhouse must allow a better control of the climate, which affects a better development of the crop and its yield.

There are different types of greenhouses for different types of crops or to cover extreme climatic changes; The greenhouse in which the numerical study of its interior climate is carried out is located in the Valle de Santiago Region, it is of the zenith type that is characterized by having wing-shaped vents in the upper part, to regulate the degree of opening of ventilation needs when the indoor climate changes, its main function is to release the hot air that accumulates in the upper part due to different factors. The total cultivable area of the greenhouse is $720 \mathrm{~m} 2$ and has 7 beds of an approximate height of 0.25 $\mathrm{m}$. where more than 200 plants are grown.

\section{Materials and methods}

The greenhouse in which the numerical analysis was carried out is of the zenith type, with two wings with a symmetrical face shape and are located in the highest part of the greenhouse, these can regulate the degree of opening according to the ventilation needs of the greenhouse, The main function is to release the hot air that for different factors accumulates in the upper part of the greenhouse.

The greenhouse dimensioning was carried out using an orthogonal mesh which consists of $90^{\circ}$ angles that formed 25 rectangles of $3.6 \mathrm{~m} \times 8 \mathrm{~m}$, the midpoint of each one was found to determine the temperature and humidity measurement point. The greenhouse has a capacity for 10 seed beds where more than 200 seeds can be sown.
The greenhouse has 10 posts that support it and its cultivable area is 40 meters long and $18 \mathrm{~m}$ wide. It is covered with a black cloth, the tubes that the greenhouse supports are $5 \mathrm{~cm}$ in diameter, it also has curtains on its sides which can be kept open to regulate the interior temperature and as protection it has a mesh that covers the curtains to avoid let in foreign matter. In addition to using the curtains for the indoor climate of the greenhouse, it has fans in the upper part, to homogenize and stabilize the temperature. The 12 fans are distributed in sections, a front and a rear along the beds. (Figure 1).

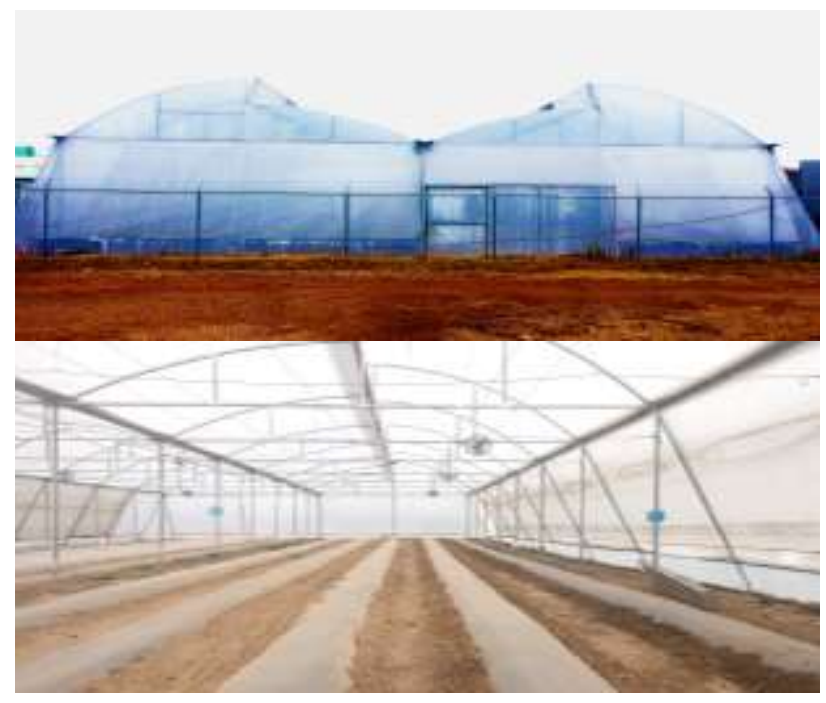

Figure 1 Indoor and outdoor view test greenhouse

\section{Orthogonal Malled}

The orthogonal meshing for the taking of parameters (Humidity and temperature) was carried out from the lower part of the greenhouse. The arable area of the greenhouse measures $40 \times 18$ meters, the orthogonal meshing was carried out at two heights 0.25 and 1.30 meters from the ground, forming a plate on this area, in the front part the 18 meters were divided into each $3.6 \mathrm{~m}$ and along the 40 meters in each $8 \mathrm{~m}$, thus forming 25 rectangles in each of the heights obtaining 50 midpoints which were used to take the parameters to be evaluated (Figure 2). 


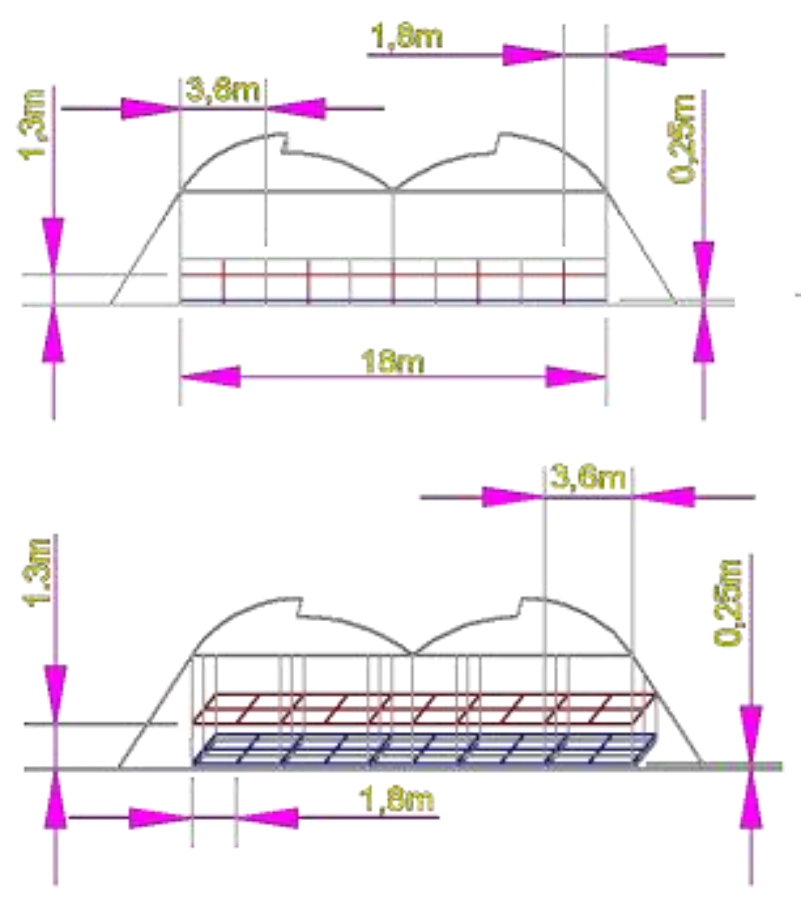

Figure 2 Front views of the orthogonal mesh of the greenhouse

As can be seen in Figure 3, the midpoints were located in each of the rectangles obtained in the orthogonal mesh of the arable area of the greenhouse, these were found at $1.8 \mathrm{~m}$

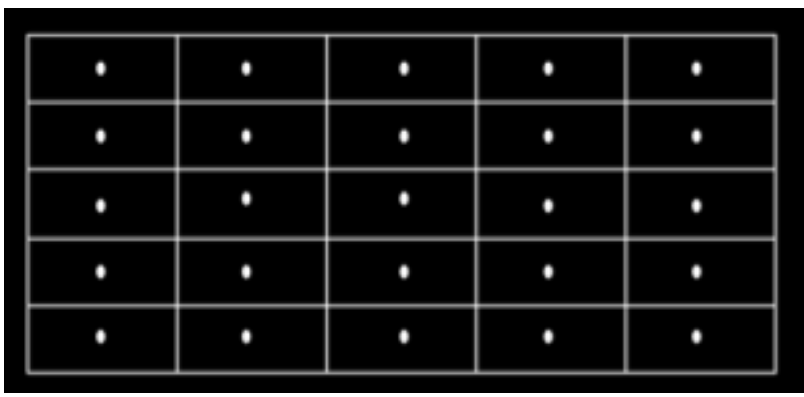

Figure 3 Top view of orthogonal meshing and midpoints

The data obtained were classified into warm days and cold days, considering the variation in temperature existing in the different days and hours; and cold days Table 1 shows an example of the data recording on a warm day and Table two shows the averages per midpoint of warm and cold days.

\begin{tabular}{|c|c|c|c|c|c|}
\hline \multicolumn{6}{|c|}{ Day 1} \\
\hline \multicolumn{6}{|c|}{ Position 1} \\
\hline Midpoint & Temperature & Humidity & Midpoint & Temperature & Humidity \\
\hline $1 \mathrm{~A}$ & 28.7 & 37 & $1 \mathrm{~B}$ & 30.2 & 40 \\
\hline $2 \mathrm{~A}$ & 28.4 & 40 & $2 B$ & 30.1 & 37 \\
\hline $3 \mathrm{~A}$ & 27.7 & 41 & $3 B$ & 30.3 & 35 \\
\hline $4 \mathrm{~A}$ & 26.3 & 36 & $4 \mathrm{~B}$ & 30.9 & 41 \\
\hline $5 \mathrm{~A}$ & 24.2 & 36 & $5 B$ & 31.6 & 36 \\
\hline
\end{tabular}

Table 1 Temperature and humidity of midpoints of a "warm day"

\begin{tabular}{|c|c|c|c|c|c|}
\hline \multicolumn{6}{|c|}{ Temperature averages by midpoint } \\
\hline \multicolumn{3}{|c|}{ Warm days } & \multicolumn{3}{|c|}{ Cold days } \\
\hline Bed level & $0.25 \mathrm{~m}$ & $1.3 \mathrm{~m}$ & Bed level & $0.25 \mathrm{~m}$ & $1.3 \mathrm{~m}$ \\
\hline Average & Average & Average & Average & Average & Average \\
\hline 30.28 & 30.15 & 30.70 & 22.6 & 23.3 & 23.6 \\
\hline 30.55 & 30.78 & 30.55 & 23.1 & 23.2 & 23 \\
\hline 30.45 & 30.50 & 30.78 & 22.7 & 22.9 & 23 \\
\hline 30.55 & 31.10 & 31.10 & 23.3 & 23.2 & 23.4 \\
\hline 30.45 & 30.93 & 31.43 & 23.7 & 23.7 & 23.1 \\
\hline 30.90 & 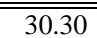 & 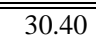 & 22.7 & 23.2 & $\overline{23.5}$ \\
\hline 30.35 & 30.60 & 30.60 & 23.3 & 23.4 & 23.2 \\
\hline 30.25 & 30.10 & 29.90 & 22.9 & 25.3 & 23.9 \\
\hline 29.95 & 30.03 & 29.85 & 24.1 & 24 & 24.1 \\
\hline 29.55 & 29.58 & 29.58 & 23.6 & 23.7 & 23.6 \\
\hline 29.43 & 29.65 & 29.73 & 22.6 & 23 & 23.2 \\
\hline 29.88 & 29.55 & 29.88 & 22.9 & 22.7 & 22.5 \\
\hline 30.15 & 30.25 & 30.30 & 22.4 & 23 & 22.9 \\
\hline 30.00 & 29.78 & 29.75 & 23 & 23.3 & 23.3 \\
\hline 29.33 & 29.18 & 29.30 & 23.2 & 23.2 & 23.7 \\
\hline 30.15 & 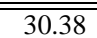 & 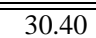 & 25.4 & 25.8 & 26.1 \\
\hline 30.38 & 30.53 & 30.83 & 24.5 & 24.8 & 25.3 \\
\hline 30.98 & 30.80 & 30.65 & 24.8 & 25.2 & 25 \\
\hline 30.73 & 30.70 & 30.73 & 24.4 & 24.7 & 25 \\
\hline 29.55 & 29.68 & 29.70 & 23.6 & 23.9 & 24.2 \\
\hline "30.38 & 31.13 & 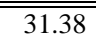 & 26.4 & 26.6 & 26.7 \\
\hline 31.40 & 31.78 & 32.15 & 25.6 & 25.3 & 25 \\
\hline 31.83 & 31.95 & 32.13 & 24.8 & 24.5 & 24.1 \\
\hline 32.00 & 32.18 & 32.50 & 24 & 24.3 & 24.3 \\
\hline 31.88 & 32.30 & 32.68 & 23.8 & 23.5 & 23.6 \\
\hline 30.45 & 30.55 & 30.68 & 23.736 & 23.988 & 23.972 \\
\hline \multicolumn{3}{|c|}{30.56} & \multicolumn{3}{|c|}{23.90} \\
\hline \multicolumn{3}{|c|}{ General Average: } & \multicolumn{3}{|l|}{27.23} \\
\hline
\end{tabular}

Table 2 Averages per midpoint warm and cold days

\section{Day without cultivation}

To obtain the value of the average function, and the heat used, the following formulas were used, the results are shown in Table 3 and Table 4, where a comparison of previous research carried out in the same greenhouse is shown.

$$
\begin{aligned}
& \iint_{R} f(x, y) d A \approx \sum_{i-1}^{4} \sum_{i-1}^{4} f(\bar{x} i, \bar{y} i) \Delta A \\
& \text { fprom }=\frac{1}{A(R)} \iint_{R} f(x, y) d A \\
& \dot{Q}=\frac{m C p\left(T_{f}-T_{i}\right)}{t}
\end{aligned}
$$

\begin{tabular}{|c|c|c|c|c|c|}
\hline \multicolumn{6}{|c|}{ Temperature ${ }^{\circ} \mathrm{C}$} \\
\hline & $\begin{array}{l}\text { S1 No } \\
\text { culture }\end{array}$ & $\begin{array}{l}\mathrm{S} 2 \quad \text { No } \\
\text { culture }\end{array}$ & $\begin{array}{l}\mathrm{S} 3 \\
\text { culture }\end{array}$ & $\begin{array}{l}\mathrm{S} 4 \\
\text { culture }\end{array}$ with & $\begin{array}{l}\text { S5 with } \\
\text { culture }\end{array}$ \\
\hline $\begin{array}{l}0.25 \\
\mathrm{~m}\end{array}$ & 27.43 & 27.52 & 29.91 & 30.93 & 24.7 \\
\hline $\begin{array}{l}1.3 \\
\mathrm{~m}\end{array}$ & 28.14 & 29.27 & 30.24 & 30.94 & 24.86 \\
\hline
\end{tabular}

Table 3 Average f results per week (0.25 and $1.3 \mathrm{~m})$ 


\begin{tabular}{|l|c|c|}
\hline \multicolumn{1}{|c|}{ Parameter } & 2017 & 2018 \\
\hline $\begin{array}{l}Q \\
\text { day seized warm }\end{array}$ & $4.83 \times 10^{-3} \mathrm{~W}$ & $0.12 \mathrm{~W}$ \\
\hline $\begin{array}{l}\text { I took } \\
\text { advantage of } \\
\text { cold day }\end{array}$ & $6.87 \times 10^{-3} \mathrm{~W}$ & $0.01 \mathrm{~W}$ \\
\hline Evaporation & $213.1488 \mathrm{Kg} \mathrm{H}_{2} \mathrm{O} / \mathrm{h}$ & $208.22 \mathrm{Kg} \mathrm{H}_{2} \mathrm{O} / \mathrm{h}$ \\
\hline Growth factor & $2-4 \mathrm{~cm}$ & $2-6 \mathrm{~cm}$ \\
\hline \multicolumn{2}{|c|}{ No crop } & \\
\hline Cooling Q & $0.49 \mathrm{~W}$ & $9.73 \mathrm{~W}$ \\
\hline Warm days & $-0.40 \mathrm{~W}$ & $-1.81 \mathrm{~W}$ \\
\hline Bed & $0.42 \mathrm{~W}$ & $0.37 \mathrm{~W}$ \\
\hline $0.5 \mathrm{~m}$ & & \\
\hline $1 \mathrm{~m}$ & &
\end{tabular}

Table 4 Data comparison for the years 2017-2018 Source: Self Made

\section{Conclusions}

This work presents the second approach to a numerical analysis of the greenhouse climate in the Valle de Santiago Guanajuato region and studying the heat transfer that exists between each of the points that were taken with the orthogonal mesh.

The temperature distribution by nodes was not uniform due to the location of the greenhouse, since at the time of obtaining the data two walls are under the sun's rays and the other two walls are under shade.

The cultivation of the plants allowed a decrease in the temperature in the greenhouse and clearly agrees with the results since, after 1 week more cultivation, the average temperature decreased $6.16^{\circ} \mathrm{C}$ and this agrees with the bibliography that the higher the volume cultivated has a greenhouse, there is a smaller difference in temperature with the outside.

\section{References}

Flores-Velázquez, Jorge, Mejía-Saenz, Enrique, Montero-Camacho, Juan I., \& Rojano, Abraham. (2011). Análisis numérico del clima interior en un invernadero de tres naves con ventilación mecánica. Agrociencia, 45(5), 545-560. Recuperado de http://www.scielo.org.mx/scielo.php?script=sci _arttext\&pid=S1405-

31952011000500002\&lng=pt\&tlng=es.

Montero, J. I., G. R. Hunt, R. Kamarudddin, A. Anton, and B. J. Bailey. 2001. Effect of ventilator configuration on wind driven ventilation in a crop protection structure for the tropics. J. Agric. Eng. Res. 80: 99-107. 